\title{
Synthesis of Santiagonamine
}

\author{
Michael D. Markey, Ying Fu, and T. Ross Kelly* \\ E.F. Merkert Chemistry Center, Boston College, Chestnut Hill, Massachusetts 02467 \\ Supporting Information
}

ross.kelly@,bc.edu

\section{Table of Contents:}

I. Experimental procedures for the synthesis of 1, 8, 9, 11-23,

$\mathbf{A}$, and $\mathbf{B}$.

(S2-S17)

II. Crystallographic structure and data of $\mathbf{1 9}$.

(S17-S18)

III. $\quad{ }^{1} \mathrm{H}$ NMR spectra of $\mathbf{1}, \mathbf{1 3 - 2 3}, \mathbf{A}, \mathbf{B}$, and ${ }^{13} \mathrm{C}$ NMR of $\mathbf{1}$. 
General Procedures. All reactions were carried out under an atmosphere of argon in flame-dried glassware. The reaction solvents tetrahydrofuran (THF), hexanes, and dichloromethane $\left(\mathrm{CH}_{2} \mathrm{Cl}_{2}\right)$ were purified by passage through activated alumina columns. ${ }^{1}$ Anhydrous $N, N$-dimethylformamide (DMF) was purchased from ACROS and stored over activated $4 \AA$ molecular sieves. Molecular sieves ( $4 \AA$ ) were activated by heating in an oven $\left(125^{\circ} \mathrm{C}\right)$ for a period of at least 48 hours. Anhydrous benzene was purchased from Aldrich. A.C.S. reagent pyridine was purchased from Aldrich and stored over $\mathrm{KOH}$ pellets. 1,4-Dioxane was distilled over $\mathrm{Na}$ and benzophenone. Triethylamine $\left(\mathrm{NEt}_{3}\right)$ was distilled over $\mathrm{CaH}_{2}$. Trifluoroacetic acid (TFA) was distilled over $\mathrm{P}_{2} \mathrm{O}_{5}$. All other reagents were used as received from the manufacturer unless otherwise stated. Flash column chromatography was carried out using Bodman reagent silica gel $60 \AA$ (32 - 63 micron). Medium pressure liquid chromatography (MPLC) was carried out using a Biotage Horizon HPFC ${ }^{\mathrm{TM}}$ system with pre-packed KPsilica gel $60 \AA$ (32-63 micron) cartridges. Reactions were monitored by thin layer chromatography (TLC) using Whatman 250 micron silica gel plates with aluminum backing and UV254 nm fluorescent indicator. All TLC plates were visualized by UV fluorescence quenching. All solution pHs were measured using EM colorpHast pH strips (Fisher, catalog number M95903). The phrase "removal of solvents in vacuo" means that solvents were removed on a rotary evaporator using a diaphragm pump (ca. 8 torr) and that remaining traces of volatiles were then removed on a high-vacuum oil pump (ca. 0.05 torr). Melting points were recorded on a Fisher-Johns melting point apparatus and are uncorrected. Infrared spectra were recorded using a Nicolet Avatar 360 FT-IR. Uv-Vis spectra were recorded on an Agilent 8453 spectrometer. ${ }^{1} \mathrm{H}$ NMR spectra were recorded on a Varian Gemini-400 $(400 \mathrm{MHz})$ spectrometer and are reported in ppm using residual solvent protons $\left(\mathrm{CDCl}_{3}=\right.$ $7.26 \mathrm{ppm}, \mathrm{DMSO}-\mathrm{d}_{6}=2.50 \mathrm{ppm}$, or $\mathrm{CD}_{2} \mathrm{Cl}_{2}=5.32 \mathrm{ppm}$ ) as an internal standard. Data are reported as: $[\delta$ shift $]([\mathrm{s}=$ singlet, $\mathrm{d}=$ doublet, $\mathrm{dd}=$ doublet of doublets, $\mathrm{ddd}=$ doublet of doublet of doublets, $\mathrm{dt}=$ doublet of triplets, $\mathrm{td}=$ triplet of doublets, $\mathrm{t}=$ triplet, $\mathrm{q}=$ quartet, $\mathrm{m}=$ multiplet, $\mathrm{br}=$ broad $],[J=$ coupling constant in $\mathrm{Hz}]$, and [integration]). Proton-decoupled ${ }^{13} \mathrm{C}$ NMR spectra were recorded on a Varian Gemini-400 (100 MHz)

\footnotetext{
${ }^{1}$ Pangborn, A.B.; Giardello, M.A.; Grubbs, R.H.; Rosen, R.K.; Timmers, F.J. Organometallics 1996, 15, 1518.
} 
spectrometer and are reported in ppm using solvent $\left(\mathrm{CDCl}_{3}=77.0 \mathrm{ppm}, \mathrm{DMSO}-\mathrm{d}_{6}=39.5\right.$ ppm, or $\mathrm{CD}_{2} \mathrm{Cl}_{2}=54.0 \mathrm{ppm}$ ) as an internal standard. Low and high resolution mass spectra were obtained at the Boston College mass spectrometry laboratory. X-ray crystallography and structure analysis for $\mathbf{2 9}$ were performed at the Boston College X-ray facility and the structure data is available as a CIF file (http://pubs.acs.org). Elemental analyses were performed by Atlantic Microlab, Inc. (Norcross, GA)

$N$-Phenyl-2-pyridinecarboxamide (8). ${ }^{2}$ A 1 L round-bottomed flask fitted with a $\mathrm{PhHN}_{\mathrm{N}}$ mineral oil bubbler and immersed in a $0{ }^{\circ} \mathrm{C}$ bath (ice and water) was charged with picolinic acid $(7,25.0 \mathrm{~g}, 203 \mathrm{mmol})$ and $\mathrm{CH}_{2} \mathrm{Cl}_{2}(400$ $\mathrm{mL})$. To the stirred suspension was added oxalyl chloride $(19.0 \mathrm{~mL}$, $223 \mathrm{mmol}$ ) dropwise over a 15 minute period followed by addition of DMF (1-2 mL, catalytic amount) in one portion, producing a rust-red color and the evolution of a gas. The mixture was kept in the cooling bath for $1 \mathrm{~h}$ and then allowed to warm to room temperature. After gas evolution ceased (ca. $8 \mathrm{~h}$ ), the mixture was again cooled to $0{ }^{\circ} \mathrm{C}$ and distilled (see above) $\mathrm{NEt}_{3}(56.6 \mathrm{~mL}, 406 \mathrm{mmol})$ was added dropwise over a 15 minute period followed by A.C.S. reagent aniline $(20.3 \mathrm{~mL}, 223 \mathrm{mmol})$ added dropwise over a 15 minute period. The brown mixture was left in the cooling bath for 30 minutes and then allowed to warm to room temperature. Stirring was continued at room temperature for $2 \mathrm{~h}$ and then the precipitate formed was collected by gravity filtration through Fisherbrand ${ }^{\circledR}$ qualitative P8 filter paper. The precipitate was washed with THF $(2 \times 75 \mathrm{~mL})$ and the filtrate and washes were combined. Removal of the solvents in vacuo gave a crude brown solid. This solid was crystallized from hexanes to give $29.6 \mathrm{~g}$ $(74 \%)$ of $8\left(\mathrm{R}_{\mathrm{f}}=0.4 ; 3: 1\right.$ hexanes/EtOAc; silica) as yellow needles: $\mathrm{mp} 74-76^{\circ} \mathrm{C}\left(\right.$ (lit. $^{2} \mathrm{mp}$ $\left.74-76^{\circ} \mathrm{C}\right)$. The spectra for 8 are in agreement with those reported in the literature. ${ }^{2}$

3-Iodo- $N$-phenyl-2-pyridinecarboxamide (9). ${ }^{3}$ To a $250 \mathrm{~mL}$ round-bottomed flask was added $8(6.00 \mathrm{~g}, 30.3 \mathrm{mmol})$ and THF $(100 \mathrm{~mL})$. The yellow solution was placed in a -78

\footnotetext{
2 (a) Jóźwiak, A.; Brzeziński, J.Z.; Płotka, M.W.; Szcześniak, A.K.; Malinowski, Z.; Epsztajn, J. Eur. J. Org. Chem. 2004, 3254. (b) Brunner, H.; Nuber, B.; Prommesberger, M. J. Organomet. Chem. 1996, 523, 179 .

${ }^{3}$ Epsztajn, J.; Płotka, M.W.; Grabowska, A. Synth. Commun. 1997, 27, 1075.
} 


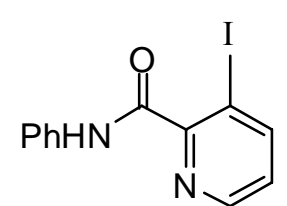

${ }^{\circ} \mathrm{C}$ bath (dry ice and acetone) and ${ }^{n} \mathrm{BuLi}(27.8 \mathrm{~mL}, 2.50 \mathrm{M}$ solution in hexane, $66.7 \mathrm{mmol}$ ) was added over a 20 minute period producing a deep-red solution. In a separate $100 \mathrm{~mL}$ pear-shaped flask was placed iodine $(9.25 \mathrm{~g}, 36.4 \mathrm{mmol})$ and THF $(80 \mathrm{~mL})$. Two hours after the addition of ${ }^{n} \mathrm{BuLi}$, the iodine solution was transferred under Ar via cannula over 25 minutes to the pyridyl dianion solution. The brown solution was left in the cooling bath for 45 minutes and then allowed to warm to room temperature. The solution was kept at room temperature for two hours and then carefully (initially dropwise) quenched with $\mathrm{H}_{2} \mathrm{O}(90 \mathrm{~mL})$. The aqueous layer was separated and extracted with EtOAc $(2 \times 60 \mathrm{~mL})$. The organics were pooled, washed with saturated sodium thiosulfate solution $(1 \times 100 \mathrm{~mL})$ and saturated $\mathrm{NaCl}$ solution $(1 \times 100 \mathrm{~mL})$, dried with $\mathrm{MgSO}_{4}$, and filtered. Removal of the solvents in vacuo gave a solid which was purified by flash column chromatography $(12 \mathrm{~cm} \times 5 \mathrm{~cm}$; silica) with 1:1 hexanes/EtOAc $(1.1 \mathrm{~L})$ to give a beige solid after concentration. This solid was crystallized from 2:1 hexanes/EtOAc to give (after three crops total) $6.20 \mathrm{~g}$ $(63 \%)$ of $9\left(\mathrm{R}_{\mathrm{f}}=0.6 ; 3: 2\right.$ hexanes/EtOAc; silica) as clear colorless prisms: mp 109-111 ${ }^{\circ} \mathrm{C}$ (lit. ${ }^{3} 106-107{ }^{\circ} \mathrm{C}$ ). The spectra for 9 are in agreement with those reported in the literature. $^{3}$

3-Hydroxy-2-iodo-4-methoxybenzaldehyde (11). ${ }^{4}$ A $250 \mathrm{~mL}$ round-bottomed flask was

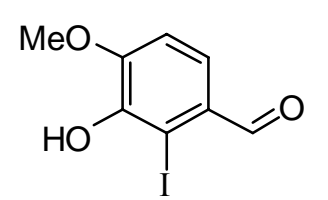
charged with isovanillin $(\mathbf{1 0}, 20.0 \mathrm{~g}, 132 \mathrm{mmol})$ and pyridine $(75$ $\mathrm{mL}$ ). The flask was immersed in a $0{ }^{\circ} \mathrm{C}$ bath (ice and water) and to the solution was added iodine monochloride $\left[1.0 \mathrm{M}\right.$ in $\mathrm{CH}_{2} \mathrm{Cl}_{2}, 132$ $\mathrm{mL}, 130 \mathrm{mmol}$, purchased from Aldrich] over a 15 minute period. The brown solution was removed from the bath and allowed to warm to room temperature. After stirring at room temperature for 4 days the solvents were removed in vacuo and to the resulting oil was added $\mathrm{H}_{2} \mathrm{O}(300 \mathrm{~mL}), 6 \mathrm{M} \mathrm{HCl}$ (until the aqueous phase had a $\mathrm{pH}=5-6$ ), and EtOAc $(100 \mathrm{~mL})$. The biphasic mixture was transferred to a separatory funnel, the layers were separated, and the aqueous layer was extracted with EtOAc $(3 \times 100 \mathrm{~mL})$. The organics were pooled, washed with $5 \%$ sodium bisulfite solution $(1 \times 100 \mathrm{~mL}), \mathrm{H}_{2} \mathrm{O}(2 \times 100 \mathrm{~mL})$,

\footnotetext{
${ }^{4}$ Markovich, K.M.; Tantishaiyakul, V.; Hamada, A.; Miller, D.D.; Romstedt, K.J.; Shams, G.; Shin, Y.; Fraundorfer, P.F.; Doyle, K.; Feller, D.R. J. Med. Chem. 1992, 35, 466.
} 
saturated $\mathrm{NaCl}$ solution ( 1 x $100 \mathrm{~mL}$ ), dried with $\mathrm{MgSO}_{4}$, and filtered. Removal of the solvent in vacuo gave $34.0 \mathrm{~g}$ of $\mathbf{1 1}$ as a yellow solid which was ordinarily carried on without purification to the subsequent reaction. Analytically pure $11\left(\mathrm{R}_{\mathrm{f}}=0.3 ; 2: 1\right.$ hexanes/EtOAc; silica) was obtained by crystallization from EtOAc to give yellow hairs: mp $168-171{ }^{\circ} \mathrm{C}$ (lit. ${ }^{4} 169-171.5^{\circ} \mathrm{C}$ ). The spectra for $\mathbf{1 1}$ are in agreement with those reported in the literature. ${ }^{4}$

2-Iodo-4-methoxy-3-(methoxymethoxy)benzaldehyde (12). ${ }^{5}$ A $250 \mathrm{~mL}$ roundMOMO bottomed flask was charged with $\mathrm{NaH}(60 \%$ dispersed in mineral oil, $5.52 \mathrm{~g}, 138 \mathrm{mmol})$. The $\mathrm{NaH}$ was washed with anhydrous hexanes $(2 \times 20 \mathrm{~mL})$ and dried in vacuo to a gray powder. The flask was immersed in a $0{ }^{\circ} \mathrm{C}$ bath (ice and water), backfilled with Ar, charged with DMF $(150 \mathrm{~mL})$, and fitted with a mineral oil bubbler. Then $11(34.0 \mathrm{~g}, 122 \mathrm{mmol})$ was added carefully (CAUTION: Rapid evolution of $\mathrm{H}_{2}$ gas!) in 5 portions over a 25 minute period producing a deep yellow color. The mixture was removed from the cooling bath, allowed to warm to room temperature, and stirred for 45 minutes. Then the flask was again cooled to $0{ }^{\circ} \mathrm{C}$ and to the mixture was added MOM-Cl $(10.2 \mathrm{~mL}, 134 \mathrm{mmol})$ dropwise over a 15 minute period. The mustard-yellow solution was removed from the cooling bath, allowed to warm to room temperature, and the progress of the reaction was monitored by TLC (desired product $\mathrm{R}_{\mathrm{f}}=0.35 ; 3: 1$ hexanes/EtOAc; silica). Once the reaction was complete (ca. 2 h), the solution was quenched (CAUTION: residual NaH may be present) with $\mathrm{H}_{2} \mathrm{O}(250 \mathrm{~mL})$ and extracted with EtOAc $(3 \times 200 \mathrm{~mL})$. The organics were pooled, washed with $\mathrm{H}_{2} \mathrm{O}(4 \times 200 \mathrm{~mL})$ and saturated $\mathrm{NaCl}$ solution $(1 \times 200 \mathrm{~mL})$, dried with $\mathrm{MgSO}_{4}$, and filtered. Removal of the solvent in vacuo gave a yellow solid (37 g). The crude yellow solid was purified in $8.0 \mathrm{~g}$ batches by flash column chromatography $(15 \mathrm{~cm}$ x $10 \mathrm{~cm}$; silica) with 2:1 hexanes/EtOAc (2 L). All batches were pooled to give $28.5 \mathrm{~g}$ (67\% over 2 steps) of $\mathbf{1 2}$ as a white solid: mp $91-93{ }^{\circ} \mathrm{C}$ (lit. ${ }^{5} 93-94{ }^{\circ} \mathrm{C}$ ). The spectra for 12 are in agreement with those reported in the literature. ${ }^{4}$

\footnotetext{
${ }^{5}$ Uchida, K.; Yokoshima, S.; Kan, T.; Fukuyama, T. Org. Lett. 2006, 23, 5311.
} 


\section{$N$-[[2-Iodo-4-methoxy-3-(methoxymethoxy)phenyl]methylene]cyclohexanamine (13).}

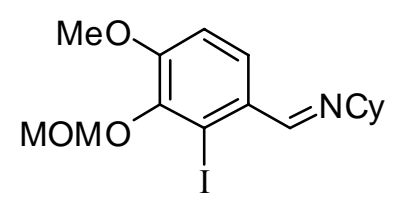

To a $100 \mathrm{~mL}$ round-bottomed flask containing activated $4 \AA$ molecular sieves (ca. $225 \mathrm{mg}$ ) was added 12 (10.0 g, $31.1 \mathrm{mmol})$ and $\mathrm{CH}_{2} \mathrm{Cl}_{2}(60 \mathrm{~mL})$. To the yellow solution was added reagentplus ${ }^{\mathrm{TM}}$ cyclohexylamine $(14.4 \mathrm{~mL}, 125 \mathrm{mmol}$, purchased from Aldrich) in one portion. The yellow solution was stirred at room temperature for $6 \mathrm{~h}$, and then filtered through a pad of Celite ${ }^{\mathrm{TM}}$. The Celite ${ }^{\mathrm{TM}}$ was rinsed with $\mathrm{CH}_{2} \mathrm{Cl}_{2}(15 \mathrm{~mL})$ and the filtrate and washes were evaporated in vacuo to give $12.3 \mathrm{~g}(98 \%)$ of $\mathbf{1 3}\left(\mathrm{R}_{\mathrm{f}}=0.5 ; 3: 1\right.$ hexanes/EtOAc, silica; the product decomposes on silica to starting material) as a beige solid: mp 111-113 ${ }^{\circ} \mathrm{C} ;{ }^{1} \mathrm{H}$ NMR (400 MHz, $\left.\mathrm{CDCl}_{3}\right) \delta 8.47$ (s, $1 \mathrm{H}$ ), 7.73 (d, $J=8.8 \mathrm{~Hz}$, $1 \mathrm{H}), 6.90(\mathrm{~d}, J=8.8 \mathrm{~Hz}, 1 \mathrm{H}), 5.16(\mathrm{~s}, 2 \mathrm{H}), 3.87(\mathrm{~s}, 3 \mathrm{H}), 3.69(\mathrm{~s}, 3 \mathrm{H}), 3.28-3.24(\mathrm{~m}, 1 \mathrm{H})$, 1.85-1.26 (m, 10H); ${ }^{13} \mathrm{C}$ NMR (100 MHz, $\left.\mathrm{CDCl}_{3}\right) \delta 161.8,153.7,145.1,131.1,124.9$, 112.3, 99.4, 98.8, 69.4, 58.5, 56.1, 34.5, 25.7, 24.8; IR (KBr) v 2918, 1625, 1585, 1484, $1448 \mathrm{~cm}^{-1}$; HRMS (ESI) calcd $\mathrm{C}_{16} \mathrm{H}_{23} \mathrm{NO}_{3} \mathrm{I}\left(\mathrm{MH}^{+}\right)$404.0723, found 404.0726; Anal. Calcd for $\mathrm{C}_{16} \mathrm{H}_{22} \mathrm{NO}_{3} \mathrm{I}$ : C, 47.66; H, 5.50; N, 3.47. Found: C, 47.82; H, 5.58; N, 3.55 .

\section{3-[6-Formyl-3-methoxy-2-(methoxymethoxy)phenyl]- $N$-phenyl-2-}<smiles>COc1ccc(C=O)c(-c2cccnc2ONc2ccccc2)c1OC</smiles>
pyridinecarboxamide (14). For a related procedure see: Kelly, T.R.; Xie, R.L. J. Org. Chem. 1998, 63, 8045. Commercially available copper bronze (Atomergic Chemetals Corp., catalog number C340E61352) was activated following Kleiderer and Adams' procedure. ${ }^{6}$ For a typical case, $5.36 \mathrm{~g}$ of copper bronze was treated with $50 \mathrm{~mL}$ of a $2 \%(\mathrm{w} / \mathrm{v})$ solution of iodine in acetone at room temperature for 12 minutes. The gray-colored copper was then collected by vacuum filtration (open to the air) and washed with acetone. The copper was subsequently stirred with a mixture of acetone $(32 \mathrm{~mL})$ and $\mathrm{HCl}(32 \mathrm{~mL}, 12.0 \mathrm{~N})$ at room temperature for 8 minutes. The copper was collected by vacuum filtration (open to the air) and washed with copious amounts of acetone. The shiny brown copper bronze was dried in a vacuum desiccator (ca. 0.05 Torr) with $\mathrm{P}_{2} \mathrm{O}_{5}$ for 35 minutes and used immediately afterward.

\footnotetext{
${ }^{6}$ Kleiderer, E.C.; Adams, R. J. Am. Chem. Soc. 1933, 55, 4219.
} 
To a $250 \mathrm{~mL}$ round-bottomed flask fitted with a glass stopcock flow control adaptor (Chemglass, catalog number CG-1028-01) was added 13 (4.00 g, 9.95 mmol), 9 (4.40 g, $13.6 \mathrm{mmol})$, and DMF (120 mL). This mixture was freeze-pump-thaw degassed three times and backfilled with Ar. Then were sequentially added tetrakistriphenylphosphine palladium(0) (1.60 g, $1.40 \mathrm{mmol}$, purchased from Strem) and activated (see above) copper bronze $(5.06 \mathrm{~g}, 79.6 \mathrm{mmol})$. The heterogeneous mixture was placed under an Ar balloon via a rubber septum, heated at $100-110^{\circ} \mathrm{C}$ for $3 \mathrm{~h}$, and then cooled to room temperature. The mixture was passed through a pad of Celite ${ }^{\mathrm{TM}}$ and the Celite ${ }^{\mathrm{TM}}$ was rinsed with EtOAc $(125 \mathrm{~mL})$. The combined filtrate and wash were added to $\mathrm{H}_{2} \mathrm{O}(800 \mathrm{~mL})$ and the resulting mixture was extracted with EtOAc $(3 \times 350$ $\mathrm{mL})$. The organics were pooled, washed with $\mathrm{H}_{2} \mathrm{O}(4 \times 300 \mathrm{~mL})$ and saturated $\mathrm{NaCl}$ solution ( 1 x $300 \mathrm{~mL})$, dried with $\mathrm{MgSO}_{4}$, and filtered. Removal of the solvent in vacuo gave $5.10 \mathrm{~g}$ of a black oil. The oil was purified by flash column chromatography $(15 \mathrm{~cm}$ x $10 \mathrm{~cm}$; silica) with 3:2 hexanes/EtOAc (2.5 L), 1:1 hexanes/EtOAc (1 L), and EtOAc $(1.2 \mathrm{~L})$ to afford $1.52 \mathrm{~g}(39 \%)$ of $14\left(\mathrm{R}_{\mathrm{f}}=0.16 ; 3: 2\right.$ hexanes/EtOAc; silica) as a white foam: mp $109-11{ }^{\circ} \mathrm{C} ;{ }^{1} \mathrm{H}$ NMR $\left(400 \mathrm{MHz}, \mathrm{CDCl}_{3}\right) \delta 10.14$ (br s, $\left.1 \mathrm{H}\right), 9.62(\mathrm{~s}, 1 \mathrm{H}), 8.68$ $(\mathrm{dd}, J=4.6,1.6 \mathrm{~Hz}, 1 \mathrm{H}), 7.78$ (d, $J=8.6 \mathrm{~Hz}, 1 \mathrm{H}), 7.69$ (dd, $J=8.0,1.6 \mathrm{~Hz}, 1 \mathrm{H}), 7.62-$ 7.59 (m, 2H), $7.55(\mathrm{dd}, J=8.0,4.6 \mathrm{~Hz}, 1 \mathrm{H}), 7.31-7.26(\mathrm{~m}, 2 \mathrm{H}), 7.10-7.05(\mathrm{~m}, 2 \mathrm{H}), 4.98$ $(\mathrm{d}, J=5.6 \mathrm{~Hz}, 1 \mathrm{H}), 4.76(\mathrm{~d}, J=5.6 \mathrm{~Hz}, 1 \mathrm{H}), 3.96(\mathrm{~s}, 3 \mathrm{H}), 2.88(\mathrm{~s}, 3 \mathrm{H}) ;{ }^{13} \mathrm{C} \mathrm{NMR}(100$

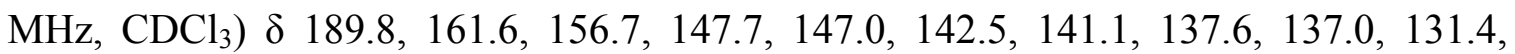
128.6, 127.8, 127.3, 125.1, 123.8, 119.6, 111.0, 98.4, 56.4, 55.8; IR (KBr) v 3331, 3945, 2841, 2749, 2354, 1683, $1589 \mathrm{~cm}^{-1}$; HRMS (ESI) calcd $\mathrm{C}_{22} \mathrm{H}_{20} \mathrm{~N}_{2} \mathrm{O}_{5} \mathrm{Na}\left(\mathrm{MNa}^{+}\right)$ 415.1270, found 415.1255 .

Also isolated on an $80 \mathrm{mg}$ scale of 13, were 14 (15 mg, 19\%) and homocoupled ${ }^{7}$ products $\boldsymbol{A}$ and $\boldsymbol{B}$.

\footnotetext{
${ }^{7}$ While not exhaustive, earlier attempts to avoid the production of homocoupling products by using Stille and, to a lesser extent, Suzuki coupling reactions on differentially functionalized partners were unsuccessful.
} 
$N, N^{\prime}$-Diphenyl-[3,3'-bipyridine]-2,2'-dicarboxamide (A). Isolated $1.0 \mathrm{mg}(1.0 \%)$ of A<smiles>O=C(Nc1ccccc1)c1ncccc1-c1ccccn1</smiles>
$\left(\mathrm{R}_{\mathrm{f}}=0.52 ; 1: 1\right.$ hexanes/EtOAc; silica $)$ as a white solid: $\mathrm{mp}$ 196-197 ${ }^{\circ} \mathrm{C} ;{ }^{1} \mathrm{H}$ NMR (400 MHz, $\left.\mathrm{CDCl}_{3}\right) \delta 10.16$ (br s, $2 \mathrm{H}$ ), $8.65(\mathrm{dd}, J=4.4,1.6 \mathrm{~Hz}, 2 \mathrm{H}), 7.63(\mathrm{dd}, J=7.6,1.6 \mathrm{~Hz}, 2 \mathrm{H})$, 7.56-7.52 (m, 6H), 7.27-7.22 (m, $4 \mathrm{H}), 7.05-7.01(\mathrm{~m}, 2 \mathrm{H}) ;{ }^{13} \mathrm{C}$ NMR (100 MHz, $\left.\mathrm{CDCl}_{3}\right) \delta 162.2,146.7,146.0,138.7,137.6,136.7,128.7,125.5,123.9$, 120.0; IR (KBr) v 3338, 3060, 1693, 1602, $1516 \mathrm{~cm}^{-1}$; HRMS (ESI) calcd $\mathrm{C}_{24} \mathrm{H}_{18} \mathrm{~N}_{4} \mathrm{O}_{2} \mathrm{Na}$ $\left(\mathrm{MNa}^{+}\right)$417.1327, found 417.1347.

\section{5,5'-Dimethoxy-6,6'-bis(methoxymethoxy)-[1,1'-biphenyl]-2,2'-dicarboxaldehyde}<smiles>COc1ccc(OC)c(-c2c(OC)ccc(C=O)c2OC)c1OC</smiles>

(B). Isolated $13 \mathrm{mg}(33 \%)$ of $\mathbf{B}\left(\mathrm{R}_{\mathrm{f}}=0.36 ; 1: 1\right.$ hexanes/EtOAc; silica) as a white solid: mp $98-100{ }^{\circ} \mathrm{C} ;{ }^{1} \mathrm{H}$ NMR $(400 \mathrm{MHz}$, $\left.\mathrm{CDCl}_{3}\right) \delta 9.57(\mathrm{~s}, 2 \mathrm{H}), 7.90(\mathrm{~d}, J=8.8 \mathrm{~Hz}, 2 \mathrm{H}), 7.13(\mathrm{~d}, J=8.8$ $\mathrm{Hz}, 2 \mathrm{H}), 4.98$ (d, $J=6.4 \mathrm{~Hz}, 2 \mathrm{H}), 4.83(\mathrm{~d}, J=6.4 \mathrm{~Hz}, 2 \mathrm{H}), 3.97$ $(\mathrm{s}, 6 \mathrm{H}), 2.88(\mathrm{~s}, 6 \mathrm{H}) ;{ }^{13} \mathrm{C}$ NMR $\left(100 \mathrm{MHz}, \mathrm{CDCl}_{3}\right) \delta 189.8$, 156.8, 144.1, 131.8, 128.9, 125.3, 111.9, 98.4, 56.4, 56.1; IR (KBr) v $1689 \mathrm{~cm}^{-1}$; HRMS (ESI) calcd $\mathrm{C}_{20} \mathrm{H}_{22} \mathrm{O}_{8} \mathrm{Na}\left(\mathrm{MNa}^{+}\right)$413.1212, found 413.1208; Anal. Calcd for $\mathrm{C}_{20} \mathrm{H}_{22} \mathrm{O}_{8}$ : C, 61.53; H, 5.68. Found: C, 61.55; H, 5.69.

\section{3-[6-Ethenyl-3-methoxy-2-(methoxymethoxy)phenyl]- $N$-phenyl-2-}

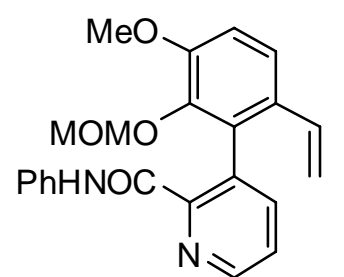
pyridinecarboxamide (22). A $50 \mathrm{~mL}$ round-bottomed flask fitted with a reflux condenser was charged with $\mathrm{K}_{2} \mathrm{CO}_{3}(552 \mathrm{mg}, 3.83$ mmol) and flame-dried under vacuum. The system was backfilled with $\mathrm{Ar}$ and to the flask was added 14 (500 $\mathrm{mg}, 1.28 \mathrm{mmol})$,

methyltriphenylphosphonium iodide (775 mg, $1.92 \mathrm{mmol}), 18$-crown-6 (2-4 mg, cat.) and DMF $(20 \mathrm{~mL})$. The mixture was heated at $100{ }^{\circ} \mathrm{C}$ under an Ar balloon and the progress of the reaction was monitored by TLC (desired product $\mathrm{R}_{\mathrm{f}}=0.49 ; 3: 2$ hexanes/EtOAc; silica). Once the reaction was complete (ca. $5 \mathrm{~h}$ ), the mixture was cooled to room temperature, quenched in one portion with $\mathrm{H}_{2} \mathrm{O}(75 \mathrm{~mL})$, and extracted with EtOAc ( $3 \mathrm{x}$ $50 \mathrm{~mL})$. The pooled organics were washed with $\mathrm{H}_{2} \mathrm{O}(3 \times 75 \mathrm{~mL})$ and saturated $\mathrm{NaCl}$ solution (1 x $75 \mathrm{~mL}$ ), dried with $\mathrm{MgSO}_{4}$, and filtered. The oil obtained upon 
concentration in vacuo was purified by flash column chromatography $(12 \mathrm{~cm} \times 4 \mathrm{~cm}$; silica) with 7:3 hexanes/EtOAc to afford $394 \mathrm{mg}$ (79\%) of 22 as a white solid: mp 115$117{ }^{\circ} \mathrm{C} ;{ }^{1} \mathrm{H}$ NMR (400 MHz, $\mathrm{CDCl}_{3}$ ) $\delta 10.01$ (br s, $1 \mathrm{H}$ ), 8.65 (dd, $J=4.8,1.8 \mathrm{~Hz}, 1 \mathrm{H}$ ), $7.68(\mathrm{dd}, J=7.6,1.8 \mathrm{~Hz}, 1 \mathrm{H}), 7.65-7.62(\mathrm{~m}, 2 \mathrm{H}), 7.52(\mathrm{dd}, J=7.6,4.8 \mathrm{~Hz}, 1 \mathrm{H}), 7.41(\mathrm{~d}$, $J=8.6 \mathrm{~Hz}, 1 \mathrm{H}), 7.31-7.26$ (m, 2H), 7.08-7.04 (m, 1H), 6.98 (d, $J=8.6 \mathrm{~Hz}, 1 \mathrm{H}), 6.20$ (dd, $J=17.4,11.0 \mathrm{~Hz}, 1 \mathrm{H}), 5.48(\mathrm{dd}, J=17.4,1.0 \mathrm{~Hz}, 1 \mathrm{H}), 4.99-4.96(\mathrm{~m}, 2 \mathrm{H}), 4.78$ (d, $J=$ $6.0 \mathrm{~Hz}, 1 \mathrm{H}), 3.89$ (s, 3H), $2.88(\mathrm{~s}, 3 \mathrm{H}) ;{ }^{13} \mathrm{C} \mathrm{NMR}\left(100 \mathrm{MHz}, \mathrm{CDCl}_{3}\right) \delta 161.8,151.5$, $148.5,146.9,142.2,141.8,137.9,134.3,133.4,133.3,129.3,128.7,125.2,123.7,121.2$, 119.6, 113.8, 111.8, 98.5, 56.4, 55.7; IR (KBr) v 3346, 2935, 1693, $1520 \mathrm{~cm}^{-1}$; HRMS (ESI) calcd for $\mathrm{C}_{23} \mathrm{H}_{23} \mathrm{~N}_{2} \mathrm{O}_{4}\left(\mathrm{MH}^{+}\right) 391.1658$, found 391.1639 .

\section{9-Methoxy-10-(methoxymethoxy)benzo[f]quinoline (23). General Considerations.}

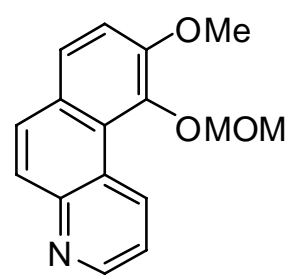

For a related procedure and description see: Kelly, T.R.; Cai, X.;

Damkaci, F.; Panicker, S.B.; Tu, B.; Bushell, S.M.; Cornella, I.; Piggott, M.J.; Salives, R.; Cavero, M.; Zhao, Y.; Jasmin, S. J. Am. Chem. Soc. 2007, 129, 376. The photoreactor, similar to Ace Glass catalog no. 7840, was a cylindrical glass vessel $(6.5 \mathrm{~cm}$ diameter x $23 \mathrm{~cm}$ tall; $250 \mathrm{~mL}$ total volume) with a quartz immersion well $(5.2 \mathrm{~cm}$ diameter) connected through a standard taper 60/40 ground glass joint. The immersion well was a double-walled quartz tube cooled by refrigerated isopropanol using a bath circulator (Thermo Neslab RTE 740). A Hanovia 450-W medium pressure quartz Hg vapor lamp (Ace Glass, Inc. catalog no. 7825-34) was placed in the immersion well and connected to a power supply (Ace Glass catalog no. 7830-60). An 8 x 50 mm magnetic stir bar was placed in the cylindrical glass vessel. The photoirradiation was monitored by electrospray ionization low resolution mass spectroscopy (LRMS) (aliquots were taken via the angle joint, evaporated to dryness, diluted to $0.1 \mathrm{mg} / \mathrm{mL}$ concentration with $\mathrm{MeOH}$ and submitted without any further work up).

Specific Procedure. To the photochemical vessel containing a magnetically stirred solution of $22(14.0 \mathrm{mg}, 0.0359 \mathrm{mmol})$ in benzene $(200 \mathrm{~mL})$ was added iodine (18.0 $\mathrm{mg}, 0.0718 \mathrm{mmol})$. The resulting purple solution was deoxygenated by bubbling Ar through it for $2 \mathrm{~h}$, using a long syringe needle reaching to the bottom of the reaction 
vessel, after which time the reaction was kept under a static Ar balloon atmosphere. A Neslab bath circulator, which was attached to the immersion well with Tygon tubing, was started; the temperature of the circulating coolant was $0{ }^{\circ} \mathrm{C}$. Propylene oxide $(300 \mu \mathrm{L}$, $4.31 \mathrm{mmol}$ ) was added, and the lamp was turned on. An elapsed time of $1.5 \mathrm{~h}$ of irradiation was required for the completion of the reaction. The resulting mixture was transferred into a flask and the solvent was removed using a rotary evaporator to give 43 $\mathrm{mg}$ of a brown residue. The residue was purified by flash column chromatography (12 $\mathrm{cm} \times 1 \mathrm{~cm}$; silica) with 7:3 hexanes/EtOAc $(75 \mathrm{~mL})$ and EtOAc $(50 \mathrm{~mL})$ to afford $8.0 \mathrm{mg}$ (83\%) of $23\left(\mathrm{R}_{\mathrm{f}}=0.61 ; 2: 3\right.$ hexanes/EtOAc; silica): ${ }^{1} \mathrm{H}$ NMR $\left(400 \mathrm{MHz}, \mathrm{CDCl}_{3}\right) \delta 10.06$ (dd, $J=8.6,1.4 \mathrm{~Hz}, 1 \mathrm{H}), 8.91(\mathrm{dd}, J=4.2,1.4 \mathrm{~Hz}, 1 \mathrm{H}), 7.87$ (d, $J=9.2 \mathrm{~Hz}, 1 \mathrm{H}), 7.83$ (d, $J=9.2 \mathrm{~Hz}, 1 \mathrm{H}), 7.69$ (d, $J=8.8 \mathrm{~Hz}, 1 \mathrm{H}), 7.52(\mathrm{dd}, J=8.6,4.2 \mathrm{~Hz}, 1 \mathrm{H}), 7.38$ (d, $J=8.8$ $\mathrm{Hz}, 1 \mathrm{H}), 5.30$ (s, 2H), 4.02 (s, 3H), 3.51 (s, 3H); $\left.{ }^{13} \mathrm{C} \mathrm{NMR} \mathrm{(100} \mathrm{MHz,} \mathrm{CDCl}_{3}\right) \delta 151.0$, 149.1, 149.0, 143.8, 136.1, 130.1, 128.8, 127.7, 126.7, 125.0, 124.3, 120.6, 113.7, 99.4, 58.3, 56.5; IR (KBr) v 3447, 2921, 1681, $1604 \mathrm{~cm}^{-1}$; HRMS (ESI) calcd for $\mathrm{C}_{16} \mathrm{H}_{16} \mathrm{NO}_{3}$ $\left(\mathrm{MH}^{+}\right)$270.1130, found 270.1125.

\section{3-[6-Formyl-2-hydroxy-3-methoxyphenyl]- $N$-phenyl-2-pyridinecarboxamide}

(15).<smiles>COc1ccc(C=O)c(-c2cccnc2C(=O)Nc2ccccc2)c1O</smiles>
To a $250 \mathrm{~mL}$ round-bottomed flask was added 14 (1.99 g, 5.08 mmol) and $\mathrm{CH}_{2} \mathrm{Cl}_{2}(75 \mathrm{~mL})$. The flask was immersed in a $0{ }^{\circ} \mathrm{C}$ bath (ice and water) and $\mathrm{TMSBr}(2.00 \mathrm{~mL}, 15.2 \mathrm{mmol})$ was added dropwise over a 5 minute period to the solution. The yellow

solution was stirred in the cooling bath for 50 minutes and then allowed to warm to room temperature. The progress of the reaction was monitored by TLC (desired product $\mathrm{R}_{\mathrm{f}}=$ 0.26; 1:1 hexanes/EtOAc; silica; a small aliquot was removed from the mixture, quenched into sat. $\mathrm{NaHCO}_{3}$, acidified (ca. $\mathrm{pH}=5-6$ ) with $1 \mathrm{M} \mathrm{HCl}$, extracted with $\mathrm{CH}_{2} \mathrm{Cl}_{2}$ and the organic layer was spotted). Once the reaction was complete (ca. $2 \mathrm{~h}$ ), the solution was quenched with sat. $\mathrm{NaHCO}_{3}(15 \mathrm{~mL})$ and $\mathrm{H}_{2} \mathrm{O}(50 \mathrm{~mL})$, acidified (ca. $\mathrm{pH}=$ 5-6) with $1 \mathrm{M} \mathrm{HCl}$ and extracted with $\mathrm{CH}_{2} \mathrm{Cl}_{2}(2 \times 40 \mathrm{~mL})$. The pooled organics were extracted with $1 \mathrm{M} \mathrm{NaOH}(5 \times 25 \mathrm{~mL})$ and the pooled aqueous layers were carefully neutralized $(\mathrm{pH}=7)$ with $6 \mathrm{M} \mathrm{HCl}$, and then extracted with EtOAc $(3 \times 50 \mathrm{~mL})$. The pooled organics were washed with saturated $\mathrm{NaCl}$ solution $(1 \times 75 \mathrm{~mL})$, dried with 
$\mathrm{MgSO}_{4}$, and filtered. Removal of the solvent in vacuo gave $1.60 \mathrm{~g} \mathrm{(91 \% )} \mathrm{of} 15$ as a white powder: mp 186-188 ${ }^{\circ} \mathrm{C} ;{ }^{1} \mathrm{H}$ NMR (400 MHz, $\mathrm{CDCl}_{3}$ ) $\delta 10.15$ (br s, $\left.1 \mathrm{H}\right), 9.66(\mathrm{~s}, 1 \mathrm{H})$, $8.69(\mathrm{dd}, J=4.8,1.6 \mathrm{~Hz}, 1 \mathrm{H}), 7.68-7.54(\mathrm{~m}, 5 \mathrm{H}), 7.31-7.27(\mathrm{~m}, 2 \mathrm{H}), 7.09-7.02(\mathrm{~m}, 2 \mathrm{H})$, $5.73(\mathrm{~s}, 1 \mathrm{H}), 4.01(\mathrm{~s}, 3 \mathrm{H}) ;{ }^{13} \mathrm{C}$ NMR $\left(100 \mathrm{MHz}, \mathrm{CDCl}_{3}\right) \delta$ 190.4, 161.8, 150.7, 147.7, 147.2, 142.4, 141.1, 137.7, 131.0, 128.8, 127.9, 127.6, 125.6, 124.3, 124.0, 119.8, 109.4, 26.2; IR (KBr) $\vee$ 3234, 2839, 2757, 1734, $1670 \mathrm{~cm}^{-1}$; HRMS (ESI) calcd for $\mathrm{C}_{20} \mathrm{H}_{16} \mathrm{~N}_{2} \mathrm{O}_{4} \mathrm{Na}\left(\mathrm{MNa}^{+}\right)$371.1008, found 371.0992.

\section{3-(6-Ethenyl-2-hydroxy-3-methoxyphenyl)- $N$-phenyl-2-pyridinecarboxamide (16).}

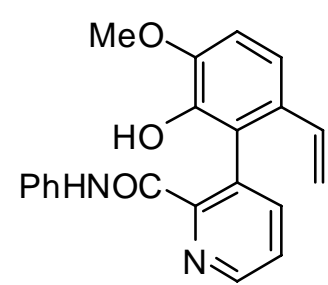

A $250 \mathrm{~mL}$ round-bottomed flask fitted with a reflux condenser was charged with methyltriphenylphosphonium iodide (4.57 g, 11.3 $\mathrm{mmol})$ and THF $(150 \mathrm{~mL})$. To the stirred white suspension was added potassium $t$-butoxide $(2.05 \mathrm{~g}, 18.1 \mathrm{mmol}$, purchased from ACROS and purified by sublimation at ca. $200-220^{\circ} \mathrm{C}$ under ca. 0.1 Torr) in one portion. The bright yellow solution was stirred at room temperature for $1 \mathrm{~h}$ followed by the addition of $15(1.57 \mathrm{~g}, 4.51 \mathrm{mmol})$ in one portion. The mixture was heated at $55^{\circ} \mathrm{C}$ and the progress of the reaction was monitored by TLC (desired product $\mathrm{R}_{\mathrm{f}}=0.23 ; 1: 1$ hexanes $/ \mathrm{Et}_{2} \mathrm{O}$; silica). Once the reaction was complete (ca. $4 \mathrm{~h}$ ), the solution was cooled to room temperature and quenched with sat. $\mathrm{NH}_{4}{ }^{+} \mathrm{Cl}^{-}(50 \mathrm{~mL})$, acidified (ca. $\left.\mathrm{pH}=5-6\right)$ with $1 \mathrm{M} \mathrm{HCl}$, and placed on the rotary evaporator to remove the THF. The aqueous mixture was extracted with $\mathrm{CH}_{2} \mathrm{Cl}_{2}(3 \times 40 \mathrm{~mL})$. The pooled organics were washed with saturated $\mathrm{NaCl}$ solution $\left(1 \times 50 \mathrm{~mL}\right.$ ), dried with $\mathrm{MgSO}_{4}$, and filtered. Removal of the solvent in vacuo gave a white foam, which was purified by flash chromatography $(15 \mathrm{~cm}$ x $4 \mathrm{~cm}$; silica) with $3: 2$ hexanes/EtOAc (1 L) to afford $1.37 \mathrm{~g}(88 \%)$ of $\mathbf{1 6}$ as a white powder: mp 186-188 ${ }^{\circ} \mathrm{C} ;{ }^{1} \mathrm{H}$ NMR $\left(400 \mathrm{MHz}, \mathrm{CDCl}_{3}\right) \delta 10.05$ (br s, $\left.1 \mathrm{H}\right), 8.65(\mathrm{~d}, J=4.0$ $\mathrm{Hz}, 1 \mathrm{H}), 7.68-764,(\mathrm{~m}, 3 \mathrm{H}), 7.53$ (dd, $J=8.0,4.0 \mathrm{~Hz}, 2 \mathrm{H}), 7.32-7.27$ (m, 2H), 7.22 (d, $J$ $=8.6 \mathrm{~Hz}, 1 \mathrm{H}), 7.09-7.05(\mathrm{~m}, 1 \mathrm{H}), 6.91(\mathrm{~d}, J=8.6 \mathrm{~Hz}, 1 \mathrm{H}), 6.25(\mathrm{dd}, J=17.6,10.8 \mathrm{~Hz}$, 1H), 5.67 (br s, 1H), 5.50 (dd, $J=17.6,1.2 \mathrm{~Hz}, 1 \mathrm{H}), 4.99$ (dd, $J=10.8,1.2 \mathrm{~Hz}, 1 \mathrm{H}), 3.92$ (s, 3H); ${ }^{13} \mathrm{C}$ NMR $\left(100 \mathrm{MHz}, \mathrm{CDCl}_{3}\right) \delta 161.8,148.2,146.9,145.7,141.9,141.8,138.0$, 134.5, 132.7, 129.3, 128.7, 125.6, 125.2, 123.8, 119.6, 116.8, 113.7, 110.0, 55.9; IR $(\mathrm{KBr}) \vee 3506,3322,3007,2937,2842,1689,1601,1525 \mathrm{~cm}^{-1}$; HRMS (ESI) calcd. 
$\mathrm{C}_{21} \mathrm{H}_{19} \mathrm{~N}_{2} \mathrm{O}_{3}(\mathrm{MH}+)$ 347.1398, found 347.1409; Anal. Calcd for $\mathrm{C}_{21} \mathrm{H}_{18} \mathrm{~N}_{2} \mathrm{O}_{3}$ : C, 72.82; H, 5.24; N, 8.09. Found: C, 72.74; H, 5.33; N, 7.82.

\section{3-(5-Bromo-6-ethenyl-2-hydroxy-3-methoxy)- $N$-phenyl-2-pyridinecarboxamide (17).}<smiles>C=Cc1c(Br)cc(OC)c(O)c1-c1cccnc1Nc1ccccc1</smiles>

The bromine-1,4-dioxane complex was prepared following the procedure described by Finkelstein. ${ }^{8}$ A $50 \mathrm{~mL}$ round-bottomed flask was charged with 1,4-dioxane $(10.0 \mathrm{~mL}, 0.117 \mathrm{~mol})$. The flask was immersed in a $0{ }^{\circ} \mathrm{C}$ bath (ice and water) and to the flask was added bromine $(6.03 \mathrm{~mL}, 0.117 \mathrm{~mol})$ dropwise over a 10 minute period. The resulting orange-red suspension was then poured into $200 \mathrm{~g}$ of crushed ice and the solids were collected by vacuum filtration. After all of the ice had melted (and the resulting water removed by vacuum filtration), the solid was stored under $\mathrm{Ar}$ in a $-20^{\circ} \mathrm{C}$ freezer.

To a $250 \mathrm{~mL}$ round-bottomed flask was added 16 (1.35 g, $3.90 \mathrm{mmol}), \mathrm{CH}_{2} \mathrm{Cl}_{2}$ $(80 \mathrm{~mL})$, and distilled (see above) $\mathrm{NEt}_{3}(5.40 \mathrm{~mL}, 39.0 \mathrm{mmol})$. The solution was cooled in a $-78^{\circ} \mathrm{C}$ bath (dry ice and acetone). To a separate $50 \mathrm{~mL}$ pear-shaped flask were added bromine-1,4-dioxane complex $(1.07 \mathrm{~g}, 4.30 \mathrm{mmol})$ and $\mathrm{CH}_{2} \mathrm{Cl}_{2}(30 \mathrm{~mL})$ at room temperature. The solution of the bromine-1,4-dioxane complex was transferred to the cooled solution of $\mathbf{1 6}$ by syringe pump (Sage Instruments, model no. 341) at a rate of $0.92 \mathrm{~mL} / \mathrm{min}$. The solution was stirred for 25 minutes in the $-78^{\circ} \mathrm{C}$ bath and then placed into a $0{ }^{\circ} \mathrm{C}$ bath. Upon warming to $0{ }^{\circ} \mathrm{C}$ the color of the solution turned from orange to purple. The solution was stirred for 30 minutes in the $0{ }^{\circ} \mathrm{C}$ bath and then allowed to warm to room temperature. After stirring at room temperature for 30 minutes the solvents were removed in vacuo to give a red solid. The solid obtained was purified by flash column chromatography $(15 \mathrm{~cm}$ x $5 \mathrm{~cm}$; silica) with $3: 2$ hexanes/EtOAc $(750 \mathrm{~mL})$ followed by 1:1 hexanes/EtOAc $(700 \mathrm{~mL})$ to afford $1.48 \mathrm{~g}(89 \%)$ of $\mathbf{1 7}\left(\mathrm{R}_{\mathrm{f}}=0.36 ; 2: 3\right.$ hexanes $/ \mathrm{Et}_{2} \mathrm{O}$; silica) as a white solid: $\mathrm{mp} 133-135{ }^{\circ} \mathrm{C} ;{ }^{1} \mathrm{H}$ NMR $\left(400 \mathrm{MHz}, \mathrm{CDCl}_{3}\right) \delta$ 10.03 (br s, 1H), 8.60 (dd, $J=4.6,1.8 \mathrm{~Hz}, 1 \mathrm{H}$ ), 7.68-7.66 (m, 2H), 7.58 (dd, $J=7.8,1.8$ $\mathrm{Hz}, 1 \mathrm{H}), 7.49$ (dd, $J=7.8,4.6 \mathrm{~Hz}, 1 \mathrm{H}), 7.33-7.29$ (m, 2H), 7.11 (s, 1H), 7.11-7.07 (m, 1H), $6.46(\mathrm{dd}, J=17.8,11.2 \mathrm{~Hz}, 1 \mathrm{H}), 5.62(\mathrm{br} \mathrm{s}, 1 \mathrm{H}), 5.13(\mathrm{dd}, J=11.2,1.6 \mathrm{~Hz}, 1 \mathrm{H})$,

\footnotetext{
${ }^{8}$ Finkelstein, B.L. In Encyclopedia of Reagents for Organic Synthesis; Paquette, L.A., Ed.; John Wiley: Chichester, 1995; Vol. 1, p 686.
} 
$4.82(\mathrm{dd}, J=17.8,1.6 \mathrm{~Hz}, 1 \mathrm{H}), 3.91(\mathrm{~s}, 3 \mathrm{H}) ;{ }^{13} \mathrm{C} \mathrm{NMR}\left(100 \mathrm{MHz}, \mathrm{CDCl}_{3}\right) \delta 161.9$, 148.1, 146.7, 145.6, 141.7, 141.6, 137.9, 134.8, 133.3, 129.7, 128.8, 126.3, 125.7, 123.9, 121.2, 119.7, 114.2, 113.1, 56.1; IR (KBr) v 3346, 3086, 2937, 1677, 1597, $1531 \mathrm{~cm}^{-1}$; HRMS (ESI) calcd. $\mathrm{C}_{21} \mathrm{H}_{17} \mathrm{~N}_{2} \mathrm{O}_{3} \mathrm{BrNa}\left(\mathrm{MNa}^{+}\right)$447.0320, found 447.0318; Anal. Calcd for $\mathrm{C}_{21} \mathrm{H}_{17} \mathrm{~N}_{2} \mathrm{O}_{3} \mathrm{Br}$ : C, 59.31; H, 4.03; N, 6.59. Found: C, 59.35; H, 4.00; N, 6.51.

9-Bromo-10-ethenyl-7-methoxy-5H-[1]benzopyrano[3,4-b]pyridin-5-one (18). To a<smiles>C=Cc1c(Br)cc(OC)c2oc(=O)c3ncccc3c12</smiles>
$100 \mathrm{~mL}$ round-bottomed flask fitted with a reflux condenser was added $17(1.48 \mathrm{~g}, 3.48 \mathrm{mmol})$, TFA $(8.77 \mathrm{~mL})$ and THF $(65 \mathrm{~mL})$. The solution was heated to $80^{\circ} \mathrm{C}$ under an Ar balloon. After stirring at 80 ${ }^{\circ} \mathrm{C}$ for $22 \mathrm{~h}$, the mixture was cooled to room temperature and the solvents were removed in vacuo to give an oil. The oil was partioned between $\mathrm{H}_{2} \mathrm{O}$ (50 $\mathrm{mL})$ and $\mathrm{CH}_{2} \mathrm{Cl}_{2}(30 \mathrm{~mL})$. The aqueous layer was basified $(\mathrm{pH}=8)$ with sat. $\mathrm{NaHCO}_{3}$ and extracted with $\mathrm{CH}_{2} \mathrm{Cl}_{2}(3 \times 30 \mathrm{~mL})$. The organics were pooled, washed with $\mathrm{H}_{2} \mathrm{O}(1$ x $30 \mathrm{~mL}$ ) and saturated $\mathrm{NaCl}$ solution $(1 \times 30 \mathrm{~mL})$, dried with $\mathrm{MgSO}_{4}$, and filtered. Removal of the solvent in vacuo gave a foam. The foam was purified by flash column chromatography (15 cm x $6 \mathrm{~cm}$; silica) with 1:4 hexanes/EtOAc to afford $884 \mathrm{mg}(76 \%)$ of $18\left(\mathrm{R}_{\mathrm{f}}=0.44\right.$, EtOAc; silica) as a white solid: mp 226-228 ${ }^{\circ} \mathrm{C}$; ${ }^{1} \mathrm{H}$ NMR (400 MHz, $\left.\mathrm{CDCl}_{3}\right) \delta 9.06(\mathrm{dd}, J=8.8,1.6 \mathrm{~Hz}, 1 \mathrm{H}), 8.88(\mathrm{dd}, J=4.4,1.6 \mathrm{~Hz}, 1 \mathrm{H}), 7.61(\mathrm{dd}, J=8.8$, $4.4 \mathrm{~Hz}, 1 \mathrm{H}), 7.29(\mathrm{~s}, 1 \mathrm{H}), 6.91(\mathrm{dd}, J=17.8,11.0 \mathrm{~Hz}, 1 \mathrm{H}), 5.74(\mathrm{dd}, J=11.0,1.2 \mathrm{~Hz}$, $1 \mathrm{H}), 5.40(\mathrm{dd}, J=17.8,1.2 \mathrm{~Hz}, 1 \mathrm{H}), 3.96(\mathrm{~s}, 3 \mathrm{H}) ;{ }^{13} \mathrm{C} \mathrm{NMR}\left(100 \mathrm{MHz}, \mathrm{CDCl}_{3}\right) \delta 157.6$, 151.0, 147.3, 140.7, 138.9, 136.0, 135.8, 132.0, 128.6, 126.8, 123.3, 120.0, 117.0, 116.9, 56.6; IR (KBr) v 1747, 1598, $1552 \mathrm{~cm}^{-1}$; HRMS (ESI) calcd. $\mathrm{C}_{15} \mathrm{H}_{10} \mathrm{NO}_{3} \mathrm{BrNa}\left(\mathrm{MNa}^{+}\right)$ 353.9742, found 353.9747 .

\section{6-Bromo-8-methoxy-10H-[1]benzopyrano[5,4,3-hij]isoquinolin-10-one (19). General}

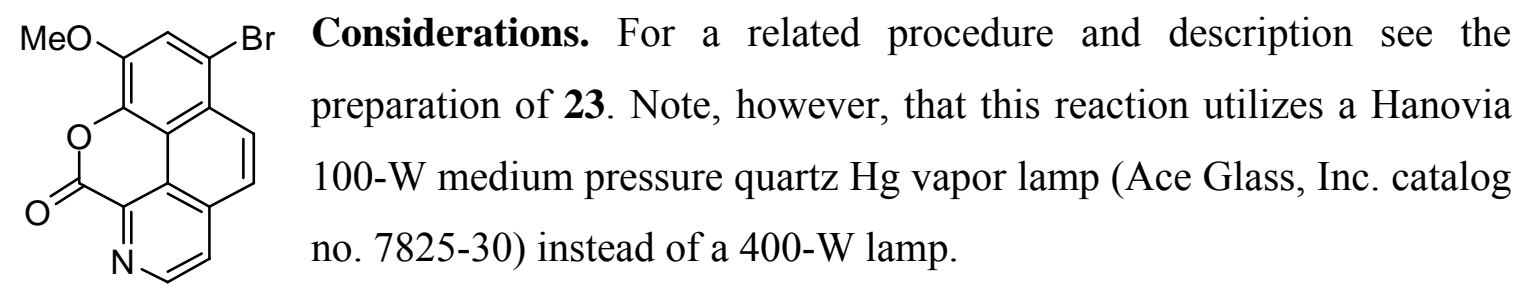


Specific Procedure. To the photochemical vessel containing a magnetically stirred solution of 18 (100 mg, $0.301 \mathrm{mmol})$ in $\mathrm{CH}_{2} \mathrm{Cl}_{2}(210 \mathrm{~mL})$ was added iodine (191 $\mathrm{mg}, 0.753 \mathrm{mmol})$. The resulting purple solution was deoxygenated by bubbling Ar through it for $2 \mathrm{~h}$, using a long syringe needle reaching to the bottom of the reaction vessel, after which time the reaction was kept under a static Ar balloon atmosphere. A Neslab bath circulator, which was attached to the immersion well with Tygon tubing, was started; the temperature of the circulating coolant was $-37^{\circ} \mathrm{C}$. Propylene oxide $(2.50 \mathrm{~mL}$, $36.1 \mathrm{mmol}$ ) was added, and the lamp was turned on. The progress of the reaction was monitored by LRMS (op. cit.). An elapsed time of 57 minutes of irradiation was required for the completion of the reaction. Over the course of the reaction the coolant temperature rose from $-37^{\circ} \mathrm{C}$ to $-18{ }^{\circ} \mathrm{C}$. The resulting mixture was transferred into a flask along with $420 \mathrm{mg}$ of silica gel and the solvent was removed using a rotary evaporator to give a brown powder. The powder was transferred into a Biotage sample holder (Barrel SLM 35 Rev. A, SBF-0035) and capped with a frit (0.890 in. dia. Porex 35 cc SLM, 0067) provided by Biotage. Purification by MPLC ( $25+\mathrm{M}$ column, equilibrate with $150 \mathrm{~mL}$ of $1: 1000 \mathrm{MeOH} / \mathrm{CH}_{2} \mathrm{Cl}_{2}$, with flow rate set to $25 \mathrm{~mL} / \mathrm{min}$ and solvent refill set to $2.0 \mathrm{~s}$ ) with $1: 1000$ to $1: 99 \mathrm{MeOH} / \mathrm{CH}_{2} \mathrm{Cl}_{2}(150 \mathrm{~mL}$; linear gradient) and 1:99 $\mathrm{MeOH} / \mathrm{CH}_{2} \mathrm{Cl}_{2}$ (650 mL; isocratic elution) yielded $89 \mathrm{mg}(89 \%)$ of $19\left(\mathrm{R}_{\mathrm{f}}=0.33 ; 4: 96\right.$ $\mathrm{MeOH} / \mathrm{CH}_{2} \mathrm{Cl}_{2}$; silica) as a yellow solid which was normally carried on to the subsequent reaction without any further purification. Analytically pure material was obtained by crystallization from $\mathrm{CHCl}_{3}$ to give yellow hairs: $\mathrm{mp} 268-270{ }^{\circ} \mathrm{C} ;{ }^{1} \mathrm{H} \mathrm{NMR}(400 \mathrm{MHz}$, $\mathrm{CDCl}_{3}$, poorly soluble) $\delta 9.20(\mathrm{~d}, J=5.2 \mathrm{~Hz}, 1 \mathrm{H}), 8.33(\mathrm{~d}, J=9.2 \mathrm{~Hz}, 1 \mathrm{H}), 8.10(\mathrm{~d}, J=$ $5.2 \mathrm{~Hz}, 1 \mathrm{H}), 7.82(\mathrm{~d}, J=9.2 \mathrm{~Hz}, 1 \mathrm{H}), 7.80(\mathrm{~s}, 1 \mathrm{H}), 4.15$ (s, 3H); ${ }^{1} \mathrm{H}$ NMR $(400 \mathrm{MHz}$, $\left.\mathrm{CD}_{2} \mathrm{Cl}_{2}\right) \delta 9.15(\mathrm{~d}, J=5.2 \mathrm{~Hz}, 1 \mathrm{H}), 8.26(\mathrm{~d}, J=9.2 \mathrm{~Hz}, 1 \mathrm{H}), 8.09(\mathrm{~d}, J=5.2 \mathrm{~Hz}, 1 \mathrm{H})$, $7.80(\mathrm{~d}, J=9.2 \mathrm{~Hz}, 1 \mathrm{H}), 7.79(\mathrm{~s}, 1 \mathrm{H}), 4.14(\mathrm{~s}, 3 \mathrm{H}) ;{ }^{13} \mathrm{C} \mathrm{NMR}\left(100 \mathrm{MHz}, \mathrm{CD}_{2} \mathrm{Cl}_{2}\right) \delta$ 155.4, 149.3, 146.2, 139.5, 137.9, 136.2, 131.1, 124.9, 124.6, 124.0, 123.6, 119.1, 118.0, 115.8 , 57.7; IR (KBr) v 3474, 1743, $1456 \mathrm{~cm}^{-1}$; HRMS (ESI) calcd $\mathrm{C}_{15} \mathrm{H}_{8} \mathrm{NO}_{3} \mathrm{BrNa}$ $\left(\mathrm{MNa}^{+}\right)$351.9585, found 351.9591; Anal. Calcd for $\mathrm{C}_{15} \mathrm{H}_{8} \mathrm{NO}_{3} \mathrm{Br}$ : C, 54.57; H, 2.44; N, 4.24. Found: C, 54.05; H, 2.42; N, 4.21. See pages S17-S18 for X-ray structure of 19. 
6-(2-Propenyl)-8-methoxy-10H-[1]benzopyrano[5,4,3-hij]isoquinolin-10-one (20). A<smiles>C=CCc1cc(OC)c2oc(=O)c3nccc4ccc1c2c43</smiles>
$100 \mathrm{~mL}$ airfree ${ }^{\circledR}$ round-bottomed flask (Chemglass, catalog no. AF0528-02) was charged with 19 (100 $\mathrm{mg}, 0.303 \mathrm{mmol})$, allyltributyl tin $(137 \mu \mathrm{L}, 0.455 \mathrm{mmol})$ and DMF $(20 \mathrm{~mL})$. The mixture was freeze-pump-thaw degassed three times under vacuum and backfilled with Ar. To the mixture was added bis(tri-t-butylphosphine)palladium(0) (9.1 $\mathrm{mg}, 0.018 \mathrm{mmol}$, purchased from Strem) in one portion. The mixture was heated to 85 ${ }^{\circ} \mathrm{C}$. After stirring at that temperature for $13 \mathrm{~h}$, the black mixture was cooled to room temperature and passed through a plug of Celite ${ }^{\mathrm{TM}}$. The Celite ${ }^{\mathrm{TM}}$ was rinsed with $\mathrm{CH}_{2} \mathrm{Cl}_{2}$ $(30 \mathrm{~mL})$. The combined filtrate and wash were added to $\mathrm{H}_{2} \mathrm{O}(75 \mathrm{~mL})$ and transferred to a separatory funnel. The aqueous layer was extracted with $\mathrm{CH}_{2} \mathrm{Cl}_{2}(3 \times 50 \mathrm{~mL})$. The organics were pooled, washed with $\mathrm{H}_{2} \mathrm{O}(4 \times 50 \mathrm{~mL})$ and saturated $\mathrm{NaCl}$ solution $(1 \times 50$ $\mathrm{mL}$ ), dried with $\mathrm{MgSO}_{4}$, and filtered. Removal of the solvent in vacuo gave a crude yellow solid. The solid obtained was purified by flash column chromatography $(12 \mathrm{~cm} \mathrm{x}$ $3 \mathrm{~cm}$; silica) with $2: 98 \mathrm{MeOH} / \mathrm{CH}_{2} \mathrm{Cl}_{2}(500 \mathrm{~mL})$ to afford $71.0 \mathrm{mg}(81 \%)$ of $20\left(\mathrm{R}_{\mathrm{f}}=\right.$ 0.42; 4:96 $\mathrm{MeOH} / \mathrm{CH}_{2} \mathrm{Cl}_{2}$; silica) as a yellow solid: mp 173-175 ${ }^{\circ} \mathrm{C} ;{ }^{1} \mathrm{H}$ NMR $(400 \mathrm{MHz}$, $\left.\mathrm{CDCl}_{3}\right) \delta 9.15(\mathrm{~d}, J=5.2 \mathrm{~Hz}, 1 \mathrm{H}), 8.19(\mathrm{~d}, J=9.6 \mathrm{~Hz}, 1 \mathrm{H}), 8.04(\mathrm{~d}, J=5.2 \mathrm{~Hz}, 1 \mathrm{H})$, $7.72(\mathrm{~d}, J=9.6 \mathrm{~Hz}, 1 \mathrm{H}), 7.41(\mathrm{~s}, 1 \mathrm{H}), 6.17-6.07$ (m, 1H), 5.18 (dd, $J=10.4,1.6 \mathrm{~Hz}, 1 \mathrm{H})$, $5.07(\mathrm{dd}, J=16.8,1.6 \mathrm{~Hz}, 1 \mathrm{H}), 4.14(\mathrm{~s}, 3 \mathrm{H}), 3.93(\mathrm{~d}, J=6.0 \mathrm{~Hz}, 2 \mathrm{H}) ;{ }^{13} \mathrm{C} \mathrm{NMR}(100$ $\left.\mathrm{MHz}, \mathrm{CDCl}_{3}\right) \delta 158.5,148.1,145.4,139.0,136.7,136.1,135.6,133.9,128.8,124.6$, 123.8, 122.6, 121.7, 117.0, 116.2, 114.8, 57.0, 36.7; IR (KBr) v 3452, 2930, 1743, 1617, 1586, $1508 \mathrm{~cm}^{-1}$; HRMS (ESI) calcd. $\mathrm{C}_{18} \mathrm{H}_{13} \mathrm{NO}_{3} \mathrm{Na}\left(\mathrm{MNa}^{+}\right)$314.0793, found 314.0800.

6-(2-Oxoethyl)-8-methoxy-10H-[1]benzopyrano[5,4,3-hij]isoquinolin-10-one (21). To<smiles>COc1cc(CC=O)c2ccc3ccnc4c(=O)oc1c2c34</smiles>
a $50 \mathrm{~mL}$ round-bottomed flask under an Ar balloon was added 20 (35 mg, $0.120 \mathrm{mmol}), \mathrm{CCl}_{4}(5.0 \mathrm{~mL}), t-\mathrm{BuOH}(2.25 \mathrm{~mL}), \mathrm{H}_{2} \mathrm{O} 7.0$ $\mathrm{mL})$, and $\mathrm{CH}_{2} \mathrm{Cl}_{2}(5.0 \mathrm{~mL})$. To the biphasic mixture was added $\mathrm{OsO}_{4}(3.1 \mathrm{mg}, 0.012 \mathrm{mmol})$ in one portion. The mixture was stirred at room temperature for 2 minutes, the color turning from yellow to black. To the mixture was added $\mathrm{NaIO}_{4}(64.0 \mathrm{mg}, 0.300 \mathrm{mmol})$ in one portion. The mixture was stirred vigorously at room temperature and the progress of the reaction was monitored by 
TLC (desired product $\mathrm{R}_{\mathrm{f}}=0.41 ; 5: 95 \mathrm{MeOH} / \mathrm{CH}_{2} \mathrm{Cl}_{2} ;$ silica). Once the reaction was complete (ca. $15 \mathrm{~h}$ ), the yellow precipitate formed (crude 21) was collected by vacuum filtration and washed with $\mathrm{CH}_{2} \mathrm{Cl}_{2}(5.0 \mathrm{~mL})$ and $\mathrm{H}_{2} \mathrm{O}(5.0 \mathrm{~mL})$. Because 21 tends to decompose upon attempted purification this material $(30.0 \mathrm{mg})$ was carried on to the next reaction without further purification: $\mathrm{mp} 166-170{ }^{\circ} \mathrm{C}(\mathrm{dec}) ;{ }^{1} \mathrm{H}$ NMR $\left(400 \mathrm{MHz}, \mathrm{CDCl}_{3}\right) \delta$ 9.90 (t, $J=2.0 \mathrm{~Hz}, 1 \mathrm{H}), 9.19$ (d, $J=5.0 \mathrm{~Hz}, 1 \mathrm{H}), 8.08$ (d, $J=5.0 \mathrm{~Hz}, 1 \mathrm{H}), 8.06$ (d, $J=$ $9.2 \mathrm{~Hz}, 1 \mathrm{H}), 7.80$ (d, J = 9.2 Hz, 1H), $7.46(\mathrm{~s}, 1 \mathrm{H}), 4.28$ (d, $J=2.0 \mathrm{~Hz}, 2 \mathrm{H}), 4.17$ (s, 3H); IR $(\mathrm{KBr}) \vee 2927,2852,1754,1621,1587,1510,1437 \mathrm{~cm}^{-1}$; HRMS (ESI) calcd for $\mathrm{C}_{17} \mathrm{H}_{11} \mathrm{NO}_{4} \mathrm{Na}\left(\mathrm{MNa}^{+}\right)$316.0586, found 316.0595 .

\section{6-[2-(Dimethylamino)ethyl]-8-methoxy-10H-[1]benzopyrano[5,4,3-hij]isoquinolin-}

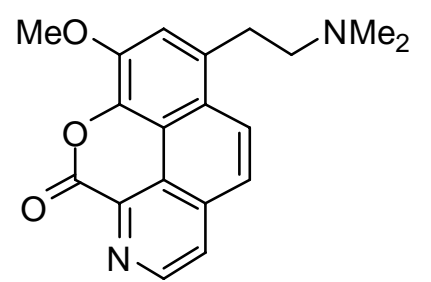

10-one (Santiagonamine, 1). A $50 \mathrm{~mL}$ round-bottomed flask was charged with 21 (30.0 $\mathrm{mg}, 0.102 \mathrm{mmol})$ and $\mathrm{CH}_{2} \mathrm{Cl}_{2}(25$ $\mathrm{mL})$. To the mixture was added $\mathrm{HNMe}_{2}(53.5 \mu \mathrm{L}, 2.0 \mathrm{M}$ in THF, $0.11 \mathrm{mmol}$, purchased from Aldrich) turning the color from yellow to orange. Then was immediately added $\mathrm{NaHB}(\mathrm{OAc})_{3}$ in several portions (ca. $4 \mathrm{mg}$ each) over a period of 10 minutes until a total of $25 \mathrm{mg}(0.118 \mathrm{mmol})$ had been added. The progress of the reaction was monitored by TLC (desired product $\mathrm{R}_{\mathrm{f}}=0.2 ; 21$ $\mathrm{R}_{\mathrm{f}}=0.6 ; 1: 1 \mathrm{MeOH} / \mathrm{CH}_{2} \mathrm{Cl}_{2}$; silica). Once complete (ca. $3 \mathrm{~h}$ ), the solvents were removed in vacuo to give a crude yellow residue. The residue was purified by flash column chromatography $\left(15 \mathrm{~cm} \times 1 \mathrm{~cm}\right.$; silica) with 10:90 $\mathrm{MeOH} / \mathrm{CH}_{2} \mathrm{Cl}_{2}(60 \mathrm{~mL}), 1: 4$ $\mathrm{MeOH} / \mathrm{CH}_{2} \mathrm{Cl}_{2}(80 \mathrm{~mL})$, and $40: 60 \mathrm{MeOH} / \mathrm{CH}_{2} \mathrm{Cl}_{2}(80 \mathrm{~mL})$ to afford $10 \mathrm{mg}(26 \%$ from 20) of 1 as an orange solid: mp 151-153 ${ }^{\circ} \mathrm{C} ;{ }^{1} \mathrm{H}$ NMR $\left(400 \mathrm{MHz}, \mathrm{CDCl}_{3}\right) \delta 9.15(\mathrm{~d}, J=$ $5.2 \mathrm{~Hz}, 1 \mathrm{H}), 8.23(\mathrm{~d}, J=9.2 \mathrm{~Hz}, 1 \mathrm{H}), 8.04(\mathrm{~d}, J=5.2 \mathrm{~Hz}, 1 \mathrm{H}), 7.75(\mathrm{~d}, J=9.2 \mathrm{~Hz}, 1 \mathrm{H})$, 7.44 (s, 1H), 4.15 (s, 3H), 3.33 (t, $J=8.0 \mathrm{~Hz}, 2 \mathrm{H}), 2.67$ (t, $J=8.0 \mathrm{~Hz}, 2 \mathrm{H}), 2.40(\mathrm{~s}, 6 \mathrm{H})$; ${ }^{13} \mathrm{C}$ NMR $\left(100 \mathrm{MHz}, \mathrm{CDCl}_{3}\right) \delta 158.5,148.1,145.4,139.0,136.7,135.6,134.7,128.5$, $124.7,123.8,122.5,121.7,116.2,114.9,61.3,57.0,45.6,31.3 ; \mathrm{UV}(\mathrm{MeOH}) \lambda_{\max }, \mathrm{nm}$ (log ع): 225 (5.08), 254 (5.02), 274 sh (4.72), 300 (4.58), 310 (4.59), 364 (4.41) nm; $\left(\mathrm{MeOH}+\mathrm{H}_{3} \mathrm{O}^{+}\right) \lambda_{\max }, \mathrm{nm}(\log \varepsilon): 228$ (5.16), 257 (5.10), 298 (4.70), 308 (4.71), 332 (4.60), 366 (4.64), 430 (4.46); IR $\left(\mathrm{CHCl}_{3}\right) \vee 1753 \mathrm{~cm}^{-1}$; HRMS (ESI) calcd. $\mathrm{C}_{19} \mathrm{H}_{19} \mathrm{~N}_{2} \mathrm{O}_{3}$ $\left(\mathrm{MH}^{+}\right)$323.1396, found 323.1407. Spectral data for synthetic $\mathbf{1}$ are in agreement with 
those reported for the natural product. ${ }^{9}$ There is a minor $(<0.1 \mathrm{ppm})$ discrepancy in the ${ }^{1} \mathrm{H}$ NMR chemical shifts of the side chain protons which we attribute to the presence of some $\mathrm{DCl}$ in the $\mathrm{CDCl}_{3}$ used to record ${ }^{9}$ the spectrum of the natural product.

\section{X-Ray Crystallographic Data and ORTEP Diagram of $\mathbf{1 9}$}

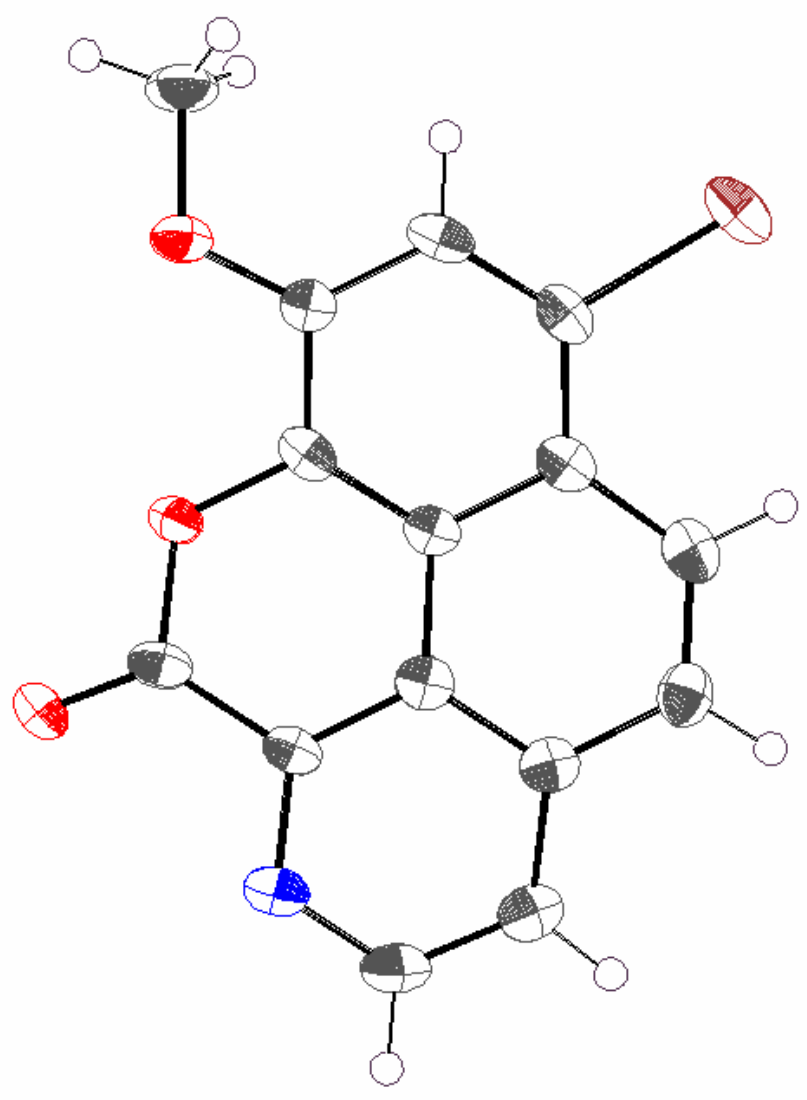

Compound crystallized with a molecule of chloroform. Chloroform is omitted for clarity.

\footnotetext{
${ }^{9}$ Valencia, E.; Patra, A.; Freyer, A.J.; Shamma, M.; Fajardo, V. Tetrahedron Lett. 1984, 25, 3163.
} 
Crystal data and structure refinement for 19.

Identification code

Empirical formula

Formula weight

Temperature

Wavelength

Crystal system

Space group

Unit cell dimensions

Volume

Z

Density (calculated)

Absorption coefficient

$\mathrm{F}(000)$

Crystal size

Theta range for data collection

Index ranges

Reflections collected

Independent reflections

Completeness to theta $=28.39^{\circ}$

Absorption correction

Max. and min. transmission

Refinement method

Data / restraints / parameters

Goodness-of-fit on $\mathrm{F}^{2}$

Final $\mathrm{R}$ indices $[\mathrm{I}>2 \operatorname{sigma}(\mathrm{I})]$

$\mathrm{R}$ indices (all data)

Largest diff. peak and hole
19

\section{C16 H9 Br Cl3 N O3}

449.50

193(2) K

$0.71073 \AA$

Monoclinic

$\mathrm{P} 2(1) / \mathrm{c}$

$$
\begin{array}{ll}
\mathrm{a}=13.344(4) \AA & \mathrm{a}=90^{\circ} . \\
\mathrm{b}=17.307(5) \AA & \mathrm{b}=100.812(4)^{\circ} . \\
\mathrm{c}=7.109(2) \AA & \mathrm{g}=90^{\circ} .
\end{array}
$$

1612.8(8) $\AA^{3}$

4

$1.851 \mathrm{Mg} / \mathrm{m}^{3}$

$3.061 \mathrm{~mm}^{-1}$

888

$0.12 \times 0.05 \times 0.01 \mathrm{~mm}^{3}$

1.55 to $28.39^{\circ}$.

$-17<=\mathrm{h}<=14,-23<=\mathrm{k}<=17,-9<=\mathrm{l}<=9$

11548

$4032[\mathrm{R}(\mathrm{int})=0.0474]$

$99.5 \%$

Empirical

0.9700 and 0.7102

Full-matrix least-squares on $\mathrm{F}^{2}$

4032 / 0 / 218

1.009

$\mathrm{R} 1=0.0461, \mathrm{wR} 2=0.1072$

$\mathrm{R} 1=0.0851, \mathrm{wR} 2=0.1229$

0.956 and -0.692 e. $\AA^{-3}$ 
$=\mathrm{NCy}$

$\frac{a}{n}$

$\mathrm{CHCl}_{3}$

Howlithow 


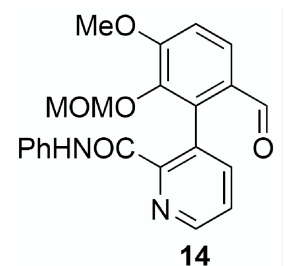

๙ิ

$\mathrm{H}_{2} \mathrm{O}$

$\mathrm{CHCl}_{3}$ 


$$
\text { (NHPh }
$$

$\mathrm{CHCl}_{3}$ 


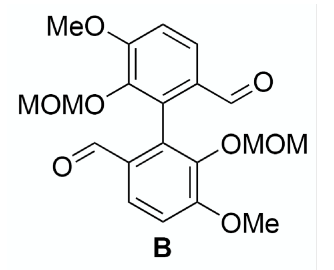




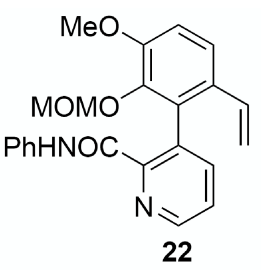

$\mathrm{CHCl}_{3}$ 


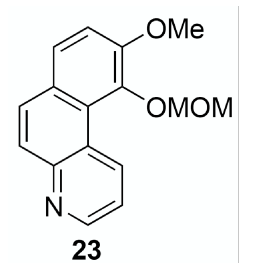




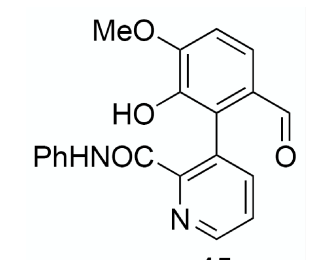

$\mathrm{CHCl}_{3}$

15 


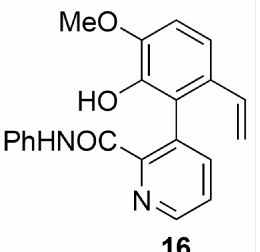




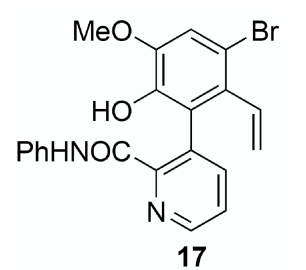



$\mathrm{CHCl}_{3}$ 


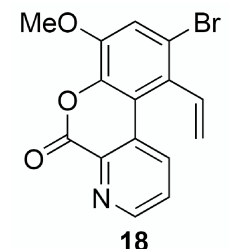

grease 


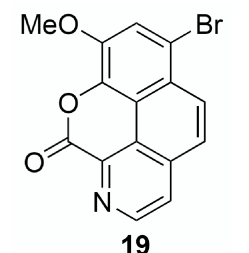

$\mathrm{CHCl}_{3}$

ฟे 


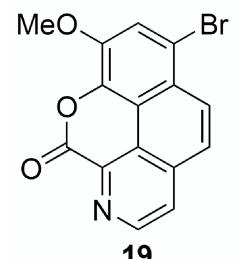




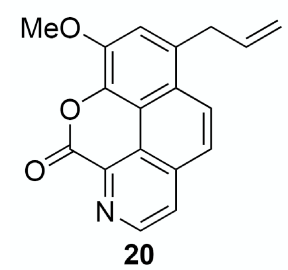

$\mathrm{CHCl}_{3}$

grease

$\mathrm{H}_{2} \mathrm{O}$ grease 


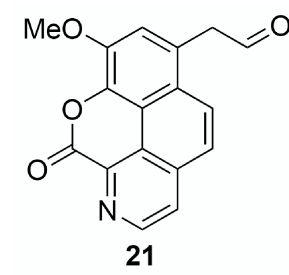

grease

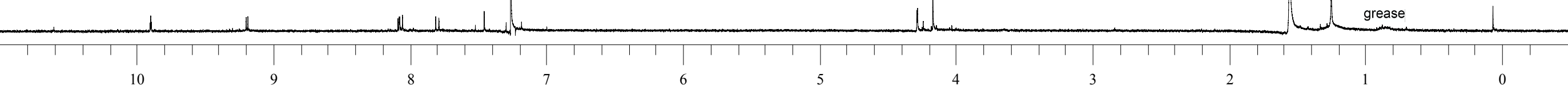




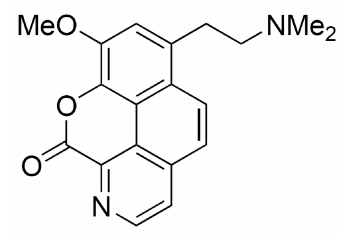

Santiagonamine 1

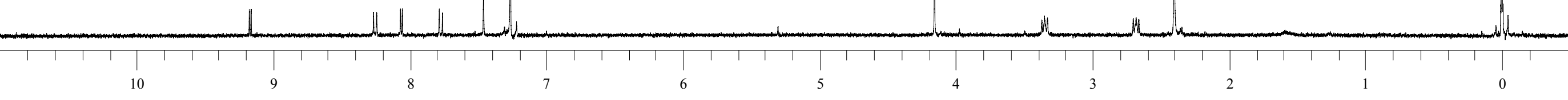




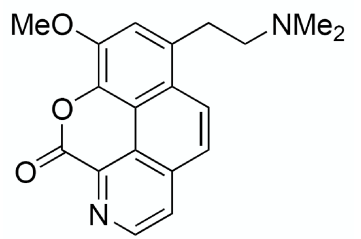

$\mathrm{CDCl}_{3}$

Santiagonamine 1 